\title{
Expression and function of human hemokinin-1 in human and guinea pig airways
}

Stanislas Grassin-Delyle ${ }^{1 *}$, Emmanuel Naline ${ }^{1}$, Amparo Buenestado ${ }^{1}$, Paul-André Risse ${ }^{1,2}$, Edouard Sage $^{3}$, Charles Advenier ${ }^{1}$, Philippe Devillier ${ }^{1}$

\begin{abstract}
Background: Human hemokinin-1 (hHK-1) and endokinins are peptides of the tachykinin family encoded by the TAC4 gene. TAC4 and hHK-1 expression as well as effects of hHK-1 in the lung and airways remain however unknown and were explored in this study.

Methods: RT-PCR analysis was performed on human bronchi to assess expression of tachykinin and tachykinin receptors genes. Enzyme immunoassay was used to quantify hHK-1, and effects of hHK-1 and endokinins on contraction of human and guinea pig airways were then evaluated, as well as the role of hHK-1 on cytokines production by human lung parenchyma or bronchi explants and by lung macrophages.
\end{abstract}

Results: In human bronchi, expression of the genes that encode for hHK-1, tachykinin $\mathrm{NK}_{1}$-and $\mathrm{NK}_{2}$-receptors was demonstrated. hHK-1 protein was found in supernatants from explants of human bronchi, lung parenchyma and lung macrophages. Exogenous hHK-1 caused a contractile response in human bronchi mainly through the activation of $\mathrm{NK}_{2}$-receptors, which blockade unmasked a $\mathrm{NK}_{1}$-receptor involvement, subject to a rapid desensitization. In the guinea pig trachea, hHK-1 caused a concentration-dependant contraction mainly mediated through the activation of $\mathrm{NK}_{1}$-receptors. Endokinin $\mathrm{A} / \mathrm{B}$ exerted similar effects to hHK-1 on both human bronchi and guinea pig trachea, whereas endokinins $C$ and D were inactive. hHK-1 had no impact on the production of cytokines by explants of human bronchi or lung parenchyma, or by human lung macrophages.

Conclusions: We demonstrate endogenous expression of TAC4 in human bronchi, the encoded peptide hHK-1 being expressed and involved in contraction of human and guinea pig airways.

\section{Background}

The mammalian tachykinins are a family of structurally related peptides which are derived from three distinct genes. TAC1 encodes for substance P (SP) and neurokinin A (NKA) through alternative splicing, while TAC3 encodes for neurokinin B (NKB) [1,2]. TAC4 was identified recently in lymphoid $B$ haematopoietic cells of the mouse bone marrow and encodes for hemokinin-1 (HK-1) [3]. The same peptide is encoded by the rat TAC4 [4] and is consequently named rat/mouse hemokinin-1 ( $\mathrm{r} / \mathrm{mHK}-1)$. In human, TAC4 encodes for hemokinin-1 (hHK-1), but its sequence is different from its murine counterpart. A more detailed analysis of the TAC4 gene in humans showed that

\footnotetext{
* Correspondence: s.grassindelyle@gmail.com

'Laboratory of pulmonary pharmacology UPRES EA220, Foch Hospital, University Versailles-Saint Quentin en Yvelines, 11 rue Guillaume Lenoir, 92150 Suresnes, France

Full list of author information is available at the end of the article
}

it is spliced into four alternative transcripts ( $\alpha, \beta, \gamma$ and $\delta$ ) that give rise to four different peptides which have been named endokinins, endokinin A (EKA), B (EKB), C (EKC) and $\mathrm{D}(\mathrm{EKD})$. Extensive TAC4 expression has been shown in a number of murine tissues including brain, spleen, stomach, skin, breast, bone marrow, thymus, prostate, uterus, skeletal muscle, lymph node, eyes, as well as in lung [5]. In human, TAC4 expression has been observed in several tissues including brain, cerebellum, thymus, prostate, testis, uterus, adrenal gland, fetal liver and spleen for $\alpha T A C 4$; heart, liver adrenal gland, bone marrow, prostate and testis for $\beta T A C 4$, whereas $\gamma$-and $\delta T A C 4$ where ubiquitously expressed, with the most prolific expression in the adrenal gland and placenta [4-6]. TAC4 expression in human lung was reported in multi-tissue cDNA expression panels, but without distinction of the different anatomical entities (bronchi, parenchyma...) [4,6]. 
The biological action of tachykinins are mediated by at least three different transmembrane G-protein coupled receptors, namely $\mathrm{NK}_{1}, \mathrm{NK}_{2}$ and $\mathrm{NK}_{3}$ receptors which are stimulated preferentially, but not exclusively by SP, NKA and NKB, respectively [7-9]. r/mHK-1 has similar affinity to SP at the human $\mathrm{NK}_{1}$ receptor $[4,6,10-12]$, while hHK-1 binds to the human $\mathrm{NK}_{1}$ receptor with a 14-fold lower affinity than SP [4]. Human HK-1 also binds to the human $\mathrm{NK}_{2}$ and $\mathrm{NK}_{3}$ receptors, with an affinity about 200-250-fold lower than for $\mathrm{NK}_{1}$ receptors $[4,10,13]$.

HK-1 is involved in a variety of biological effects. Many studies have focused on its actions on immunological regulation and inflammation. Indeed, $\mathrm{r} / \mathrm{mHK}-1$ was initially found to be an important growth and survival factor for mouse early B-cells [3,14-16] and can play a role in murine T-cell development [15]. With respect to smooth muscle preparations, $\mathrm{r} / \mathrm{mHK}-1$ was found to cause a relaxation of the porcine coronary arteries [17] but to induce a contraction of the isolated rat urinary bladder [10], mouse and human uterus [18,19]. hHK-1 was also able to induce coronary vasodilatation followed with coronary vasorelaxation in the isolated guinea pig heart [20]. Numerous reports have focused on the involvement of the nonadrenergic noncholinergic system in the regulation of airway tone, demonstrating contractile properties for SP and NKA in human bronchi [21-25] and guinea pig airways $[23,26]$. Tachykinins released from the sensory unmyelinated $\mathrm{C}$-fibers can cause the contraction of airway smooth muscle, an increase in vascular permeability, glandular secretion, and in cholinergic neurotransmission [27]. Tachykinins have been also involved in the recruitment and the activation of inflammatory cells such as mast cells [28], eosinophils [29], neutrophils [30,31], lymphocytes [32], monocytes and macrophages [33]. Tachykinins are also produced by immune and inflammatory cells airway smooth muscle cells, endothelial and epithelial cells, and fibroblasts [3,14,34-36]. This non neuronal production may be involved in the pulmonary effects of tachykinins. These peptides can induce bronchoconstriction in man, asthmatics being more sensitive than normal subjects, in agreement with the in vitro enhanced sensitivity and maximal response to tachykinins of human bronchi pretreated with serum from patients with atopic asthma [37]. However, in contrast to the characterization of SPor NKA-mediated effects, little is known about the expression of hHK-1 and the contractile and inflammatory effects of this peptide in human airways. Thus, the aims of the present study were to determine the presence of tachykinins, tachykinin receptors and tachykinins degrading enzyme neutral endopeptidase (NEP) mRNAs, and hHK-1 protein in human bronchial tissues, and to characterize the effects of hHK-1, EKA/B (common
C-terminal decapeptide of EKA and EKB $[6,38])$, EKC and EKD in human and guinea-pig isolated airways. Finally, effects of hHK-1 on the production of cytokines by explants of human bronchi or lung parenchyma and by human lung macrophages were assessed in comparison to those of SP. We report for the first time the endogenous expression of TAC4 and hHK-1 in human bronchi, together with a role of hHK-1 and endokinins in the contraction of human and guinea pig airways.

\section{Methods}

Human bronchi and guinea pig airways preparations

Human bronchial tissues were removed from 47 patients undergoing surgical resection at Foch Hospital (Suresnes, France) or Val d'or Clinic (Saint Cloud, France) for lung cancer (31 men and 16 women; age $=64 \pm 9$ years). Just after resection, segments of human bronchi with an inner diameter (ID) of 1 to $3 \mathrm{~mm}$ were taken as far as possible from the malignant lesion. Male Hartley guinea pigs (Charles River, L'Arbresle, France) weighing 300 to $350 \mathrm{~g}$ were sacrificed by cervical dislocation, and tracheas and proximal bronchi were removed. After the removal of adhering lung parenchyma and connective tissues, rings from human bronchi (5-7 mm long, 0.5-1 mm ID) and guinea pig trachea ( $3 \mathrm{~mm}$ long, $3 \mathrm{~mm}$ ID) or proximal airways ( $3 \mathrm{~mm}$ long, $1 \mathrm{~mm} \mathrm{ID)} \mathrm{were} \mathrm{prepared.}$ 8 to 24 segments of human bronchi were obtained from each patient, whereas 8 trachea segments and 2 to 3 main bronchi segments were obtained from each guinea pig. For RT-PCR analysis, human bronchi were isolated within 1 hour after resection, immediately disrupted and homogenized in TRIzol reagent (Invitrogen) with a Potter Elvehjem homogenizer, and homogenates were kept frozen at $-80^{\circ} \mathrm{C}$ until mRNA extraction. Experiments with human lung tissues were approved by the Regional Ethics Committee for Biomedical Research and animals were used as recommended by animal care guidelines.

\section{Reverse Transcriptase-Polymerase Chain Reaction (RT- PCR)}

Total RNA was extracted from human bronchi $(n=4)$ using TRIzol reagent. After a DNase step (DNase I, Invitrogen), total RNA (1 $\mu \mathrm{g})$ was reverse-transcribed using a High Capacity RNA-to-cDNA Synthesis Kit (Applied Biosystems, Les Ulis, France). The resulting product (cDNA) was used as template in endpoint or real-time PCR. Amplification was performed from $20 \mathrm{ng}$ cDNA with Power SYBR Green PCR Master Mix (Applied Biosystems) in a MiniOpticon Real-Time PCR Detection System (Bio-Rad, Marnes-la-Coquette, France). Thermal cycling conditions were designed as follows: initial denaturation at $95^{\circ} \mathrm{C}$ for $10 \mathrm{~min}$, followed by 40 cycles at $95^{\circ} \mathrm{C}$ for $15 \mathrm{sec}$ and $60^{\circ} \mathrm{C}$ for $1 \mathrm{~min}$. Total reaction volume was $25 \mu \mathrm{L}$ with $300 \mathrm{nM}$ of each reverse and forward primer. 
The primers used for tachykinins and their receptors were designed against sequences common to all described isoforms and were synthesized by Eurogentec (Angers, France). The primer pairs used for PCR were as follows: 5'-AAAGGGCTCCGGCAGTTC-3' and 5'-TGCAGAAGAAATAGGAGCCAATG-3' for TAC1; 5'-GAAGTCATGCATGTCACGTTTCTC-3' and 5'GACTCTTCAAAAGCCACTCATCTCT-3' for TAC3; 5'-TACGGCGAAGCTGTGCATT-3' and 5'-TCACACAAGGCCCACACTGA-3' for TAC4; 5'-GTAGGGCAGGAGGAAGAAGATGT-3' and 5'-CAAGGTGGT CAAAATGATGATTGT-3' for TACR1; 5'-GAGGCCGATGACGCTGTAG-3' and 5'-CAAGACGCTCCTC CTGTACCA-3' for TACR2; 5'-ATATACCTGTCCACCGCAATGG-3' and 5'-CGCTTCCAGAACTTCTT TCCTATC-3' for TACR3. Expected amplicon sizes were $91,110,90,85,84$ and 80 bp respectively. For NEP, primer pair was 5'-GGAGCTGGTCTCGGGAATG-3' and 5'-AGCCTCTCGGTCCTTGTCCT-3' [39] (amplicon expected size: $219 \mathrm{bp}$ ). To control for the recovery of intact cellular RNA and for the uniform efficiency of each reverse transcription reaction, a hypoxanthine phosphoribosyltransferase (HPRT) fragment was amplified by real-time RT-PCR (primer pair: 5'-TAATCCAGCAGGTCAGCAAAG-3' and 5'-CTGAGGATTTGGAAAGG GTGT-3'; expected size: $157 \mathrm{bp}$ ) on the same plate as that with tachykinins or tachykinins receptors cDNAs. The absence of secondary, non-specific amplification products in our experiments was assessed by analyzing melting curves and by separating PCR reaction products on agarose gel. The identity of each PCR product was established by DNA sequence analysis. With each sample, control samples without the RT step or with water instead of cDNA template were amplified to ensure there was no genomic DNA contamination and that all reagents were free of target sequence contamination. For each tachykinin and tachykinin receptor gene, a positive control sample of human fetal brain total mRNA (Ozyme, Saint Quentin en Yvelines, France) was also included in each run.

\section{In vitro bronchomotor responses}

Human bronchial rings and guinea pig tracheal and bronchial rings were suspended on hooks in $5 \mathrm{~mL}$ organ bath containing a modified Krebs-Henseleit solution $\left(\mathrm{NaCl} 119, \mathrm{KCl} 4.7, \mathrm{CaCl}_{2} 2.5, \mathrm{KH}_{2} \mathrm{PO}_{4} 1.2, \mathrm{NaHCO}_{3} 25\right.$ and glucose $11.7 \mathrm{mM}$ ), maintained at $37^{\circ} \mathrm{C}$ and oxygenated with $95 \% \mathrm{O}_{2}$ and $5 \% \mathrm{CO}_{2}$. An initial tension of $2 \mathrm{~g}$ was applied to tissues, according to previously described protocols $[21,26]$. Changes of tension were measured isometrically with Gould strain gauges (UF1; Piodem, Canterburry, Kent, UK); and were recorded and post-processed with IOX and Datanalyst softwares (Emka Technologies France, Paris). During the initial stabilization period $(30 \mathrm{~min})$, tissues were washed every 10 minutes with Krebs-Henseleit solution. Phosphoramidon was used to inhibit enzymatic degradation of tachykinins by NEP [21,40]. Phosphoramidon $\left(10^{-6}\right.$ $\mathrm{M})$ was added in organ bath with or without $\mathrm{NK}_{1^{-}}$, $\mathrm{NK}_{2}{ }^{-}$or $\mathrm{NK}_{3}$-receptor antagonists (SR 140333, SR 48968 and SR $142801,10^{-7} \mathrm{M}$ ) after the first stabilization period. Antagonist concentrations were chosen based on their reported affinities for human tachykinin receptors [41-43] and on their ability to antagonize HK-1-induced responses at similar concentrations in other models $[10,13,44]$. Tissues were then equilibrated 1 hour and concentration-response curves to tachykinins and related peptides were established by applying cumulative concentrations of peptides at 5 to $10 \mathrm{~min}$ intervals in semi-logarithmic increments, or by applying a single concentration of peptide. Only one concentration-response curve to tachykinins was recorded in each strip, and each experiment was performed in duplicate. Maximal response was determined by a final addition of acetylcholine hydrochloride (ACh, $3 \mathrm{mM}$ ). Contractile responses to tachykinins and related compounds were expressed as percentage of that induced by $\mathrm{ACh}$. The $\mathrm{pD}_{2}$ (defined as the negative log of the molar drug concentration that caused $50 \%$ of maximal effect) were calculated from the log concentrationeffect curves. When the $\mathrm{pD}_{2}$ value was not assessable (maximal effect $\left(E_{\max }\right)$ not reached), it was replaced by the $-\log \mathrm{EC}_{20}$ (defined as the negative log of the drug concentration that caused $20 \%$ of maximal contraction with $\mathrm{ACh}$ ). All values in the text and in the figures are expressed as arithmetic mean \pm standard error of the mean (s.e.m) of duplicate experiments on tissues from the given $(n)$ number of individuals or animals.

\section{Short-term culture of human bronchi and lung parenchyma explants and of lung macrophages}

Explants of lung parenchyma and bronchi were prepared according to Mitsuta et al. [45]. Briefly, small bronchi ( $1 \mathrm{~mm}$ ID) removed from 4 patients and lung parenchyma from 6 patients were cut under sterile conditions into small fragments and rinsed once in RPMI 1640 supplemented with antibiotics $(100 \mu \mathrm{g} / \mathrm{mL}$ streptomycin and $100 \mathrm{U} / \mathrm{mL}$ penicillin) and $2 \mathrm{mM}$ L-glutamine. Explants were then conserved overnight at $+4^{\circ} \mathrm{C}$ in RPMI supplemented medium. Fragments $(\approx 50 \mathrm{mg}$ ) were pre-incubated in 12-well (bronchi) or 6-well (parenchyma) culture plates for 1 hour $\left(37^{\circ} \mathrm{C}\right.$, $\left.5 \% \mathrm{CO}_{2}\right)$ in the presence of phosphoramidon $\left(10^{-6} \mathrm{M}\right)$ in $2.5 \mathrm{~mL}$ (bronchi) or $5 \mathrm{~mL}$ (parenchyma) of RPMI supplemented medium, before hHK-1 or SP (both $10^{-9}$ to $10^{-5} \mathrm{M}$ ) was applied.

Lung macrophages from 6 patients were isolated and cultured as previously described [46] and exposed to 
either hHK-1 or SP (both $10^{-9}$ to $10^{-5} \mathrm{M}$ ) after a 1-hour pre-incubation with phosphoramidon $\left(10^{-6} \mathrm{M}\right)$. After a 24 hour incubation of bronchi and parenchyma explants or lung macrophages, supernatants were collected, centrifuged and frozen at $-80^{\circ} \mathrm{C}$ until subsequent cytokine quantification.

\section{Cytokines and hHK-1 assays}

Cytokines production (TNF- $\alpha$, IL-6, IL-8, MIP- $1 \alpha$, MCP-1, ENA-78, GRO- $\alpha$, MIG, and MIF) was assessed by measuring their concentrations in the culture supernatants with enzyme-linked immunosorbent assays (ELISA, Duoset Development System), according to the manufacturer's instructions (R\&D Systems Europe, Lille, France). hHK-1 concentrations were determined with enzyme immunoassay (EIA) according to the manufacturer's instructions (Bachem, Weil am Rhein, Germany). Specifications of this EIA indicate absence of crossreactivity with SP, NKA or NKB, and appropriate negative (RPMI alone) and positive (RPMI spiked with hHK-1) controls were included in the assay. Supernatants were diluted as appropriate and the optical density was determined at $450 \mathrm{~nm}$ with an MRX II microplate reader from Dynex Technologies (Saint-Cloud, France). Concentrations were expressed as pg per $100 \mathrm{mg}$ tissue (bronchi and parenchyma explants) or pg per million cells (lung macrophages). The detection limits of these assays were $8 \mathrm{pg} / \mathrm{ml}$ for MIP- $1 \alpha, 9 \mathrm{pg} / \mathrm{ml}$ for IL-6, $16 \mathrm{pg} / \mathrm{ml}$ for TNF- $\alpha$, MCP-1 and ENA-78, $32 \mathrm{pg} / \mathrm{ml}$ for IL-8, GRO- $\alpha$ and MIF, and $62 \mathrm{pg} / \mathrm{ml}$ for MIG.

\section{Sources of chemicals and reagents}

Substance P (RPKPQQFFGLM-NH $\left.{ }_{2}\right),\left[\operatorname{Sar}^{9}, \operatorname{Met}\left(\mathrm{O}_{2}\right)^{11}\right]$ substance $\mathrm{P}$ (selective for $\mathrm{NK}_{1}$ receptors), neurokinin $\mathrm{A}$ (HKTDSFVGLM-NH ${ }_{2}$ ), [ $\beta$-Ala ${ }^{8}$ ]-NKA (4-10) (selective for $\mathrm{NK}_{2}$ receptors), neurokinin B (DMHDFFVGLM$\mathrm{NH}_{2}$ ) were provided from Bachem and human hemokinin-1 (TGKASQFFGLM-NH ${ }_{2}$ ) from NeoMPS (Strasbourg, France). Custom synthesized endokinin A/B, endokinin $C$ and endokinin D were supplied from Phoenix Pharma (Belmont, California, USA), SR 140333 ((S) 1-(2-[3-(3,4-dichlorophenyl)-1-(3-isopropoxyphenylacetyl)piperidin-3-yl] ethyl)-4-phenyl-1-azoniabicyclo [2.2.2] octane chloride), SR 48968 ((S)-N-methyl-N[4-acetylamino-4-phenylpiperidino-2-(3,4-dichlorophenyl) butyl]benzamide) and SR $142801((\mathrm{~S})-(\mathrm{N})$-(1-(3-(1-benzoyl-3-(3,4-dichlorophenyl)piperidin-3-yl)propyl)-4phenylpiperidin-4-yl)-N-methylacetamide) were kindly provided by Dr Emonds-Alt (Sanofi Research Center, Montpellier, France) and dissolved in ethanol. Phosphoramidon (N-( $\alpha$-L-rhamnopyranosyloxyhydroxyphosphinyl)L-leucyl-L-tryptophan), penicillin/streptomycin stabilized solution, L-glutamine and acetylcholine hydrochloride were obtained from Sigma (Saint Louis, MO, United States); RPMI 1640 medium from Eurobio Biotechnology (Les Ulis, France). All tachykinins except NKB were dissolved in sterile distilled water and kept in aliquots at $-20^{\circ}$ $\mathrm{C}$ until used. Solutions of NKB were prepared in $20 \%$ dimethylsulfoxide and then diluted in distilled water. Maximal final concentrations of dimethylsulfoxide achieved in organ baths were found to have no effect on resting bronchial tone and on acetylcholine-induced responses.

\section{Statistical analysis of results}

GraphPad Prism software (version 5.01 for Windows, GraphPad Software ${ }^{\oplus}$, San Diego California, United States) was used to determine $\mathrm{pD}_{2}$ and $\mathrm{E}_{\max }$ and to perform a statistical analysis of the results, using ANOVA followed with Bonferroni post-tests. A $p$ value lower than $0.05(p<0.05)$ was considered to be significant.

\section{Results}

Tachykinins, tachykinin receptors and neutral endopeptidase expression

In human bronchi, TAC4, TACR1 and TACR2 mRNAs were found in all samples whereas TAC1 and TACR3 mRNAs were not detected (fig. 1). A low TAC3 mRNA expression was found for one patient only, and NEP mRNA was expressed in high amounts in three of the four samples. All of these mRNAs were highly expressed in fetal brain positive control samples, except TACR2 mRNA which was not found in this tissue.

In addition to TAC4 mRNA expression, hHK-1 protein was found in the supernatants of bronchial explants $(1.40 \pm 0.31 \mathrm{pg} / 100 \mathrm{mg}(n=11))$, parenchyma explants $(1.15 \pm 0.29 \mathrm{pg} / 100 \mathrm{mg}(n=11))$ and lung macrophages $\left(1.85 \pm 0.89 \mathrm{pg} / 10^{6}\right.$ cells $\left.(n=6)\right)$ cultured for 24 hours in the presence of phosphoramidon.

\section{Characterization of hHK-1- and endokinins-induced responses in human airways Contractile effects of $h H K-1$ and endokinins in isolated human bronchi}

On human isolated bronchi and in the presence of phosphoramidon, hHK-1 produced concentrationdependent contractions reaching $80 \pm 2 \%$ of the contraction induced by acetylcholine with a $\mathrm{pD}_{2}$ of $5.6 \pm$ $0.2(\mathrm{n}=12)$ (fig. $2 \mathrm{~A})$. In comparison, $\mathrm{E}_{\max }$ and $\mathrm{pD}_{2}$ values for the contractions induced by the $\mathrm{NK}_{2}$ receptor agonist NKA were $87 \pm 1 \%$ and $8.5 \pm 0.1$ (curves not shown). EKA/B caused concentration-dependent contraction on human isolated bronchi and was equipotent to hHK-1 (respective $-\log \mathrm{EC}_{20}$ of $7.2 \pm 0.3(n=3)$ and $7.0 \pm 0.5(n=3))$, whereas EKC and EKD were devoid of any contractile activity (fig. 2B). 


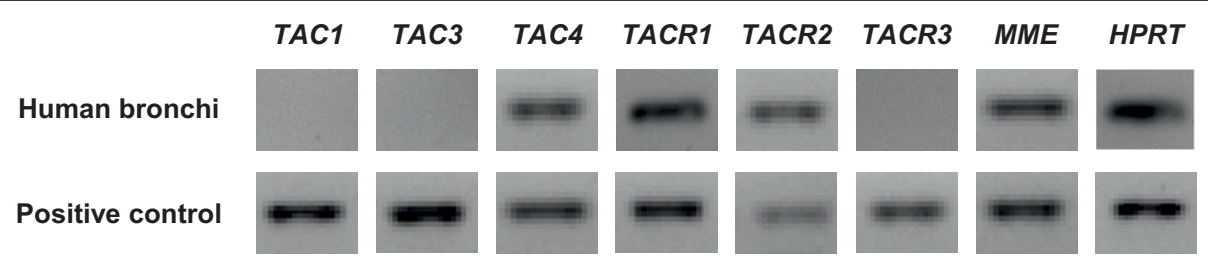

Figure 1 Expression of tachykinin, tachykinin receptor and NEP mRNAs in human bronchi. RT-PCR product of the housekeeping gene HPRT used as normalization standard is also represented. Equal aliquots of each cDNA sample (human bronchi or human fetal brain positive control) were amplified for 40 PCR cycles with their respective specific primer pairs. Since TACR2 was not expressed in human fetal brain, another bronchi sample was used as positive control for this gene.

\section{Effects of tachykinin receptor antagonists on cumulative additions of hHK-1 to human bronchi}

The $\mathrm{NK}_{2}$ receptor antagonist SR $48968\left(10^{-7} \mathrm{M}\right)$, completely abolished the contractile effects of cumulative additions of hHK-1 on human isolated bronchi, whereas the $\mathrm{NK}_{1}$ receptor antagonist SR $140333\left(10^{-7} \mathrm{M}\right)$ only exerted a small but not statistically significant reduction of hHK-1-induced contraction at the lowest concentrations $\left(10^{-8} \mathrm{M}-10^{-7} \mathrm{M}\right)$ (fig. $\left.2 \mathrm{~A}\right)$. Finally, the $\mathrm{NK}_{3}$ receptor antagonist SR $142801\left(10^{-7} \mathrm{M}\right)$ did not alter the concentration-response curve to hHK-1.

\section{Desensitization of the human tachykinin $\mathrm{NK}_{1}$ receptor}

Since a rapid $\mathrm{NK}_{1}$ receptor desensitization has been reported in human isolated bronchi [22], and in order to clarify the role of the $\mathrm{NK}_{1}$ receptor in the responses to hHK-1, we compared the effects of single or cumulative additions of hHK-1 and of the specific $\mathrm{NK}_{1}$ receptor agonist $\left[\mathrm{Sar}^{9}, \operatorname{Met}\left(\mathrm{O}_{2}\right)^{11}\right]$ SP. Experiments were performed in the presence of the $\mathrm{NK}_{2}$ receptor antagonist SR $48968\left(10^{-7} \mathrm{M}\right)$ to block the $\mathrm{NK}_{2}$ receptor-mediated component. Cumulative additions of both peptides induced small contractions of human isolated bronchi
$\left(E_{\max }=9 \pm 3 \%\right.$ and $13 \pm 3 \%$, respectively), characterized by inverted $U$-shaped concentration-response curves (fig. 3A and 3B). On the other hand, single additions of hHK-1 or $\left[\mathrm{Sar}^{9}, \mathrm{Met}\left(\mathrm{O}_{2}\right)^{11}\right]$ SP did not lead to an inverted $\mathrm{U}$-shaped curve but to a sigmoid response curve, and maximal contractions reached $43 \pm 5 \%$ and $26 \pm 7 \%$ respectively, with $\mathrm{pD}_{2}$ values of $6.6 \pm 0.3(n=$ 5-7) and 8.0 $\pm 0.4(n=10)$. In contrast, concentrationresponse curves for NKA and hHK-1 in the presence of the $\mathrm{NK}_{1}$ receptor antagonist SR $140333\left(10^{-7} \mathrm{M}\right)$ were similar whatever the protocol used (fig. 3C and 3D).

Effects of tachykinin receptor antagonists on single addition of $\mathrm{hHK}-1$ to human bronchi

SR 140333 and SR 48968 reduced weakly but not significantly the response of human bronchi to a single addition of $10^{-6} \mathrm{M}$ hHK- 1 ( $31 \pm 5 \%$ and $31 \pm 4 \%$ respectively, versus control $42 \pm 4 \%(n=6-12))$ (fig. $4 \mathrm{~A})$. However, the association of both SR 140333 and SR 48968 was synergic and abolished the smooth muscle contraction. In contrast, the response to $\left[\mathrm{Sar}^{9}, \operatorname{Met}\left(\mathrm{O}_{2}\right)^{11}\right]$ SP $\left(10^{-6} \mathrm{M}\right)$, was specifically abolished by SR 140333 but unmodified by SR 48968 (fig. 4B).
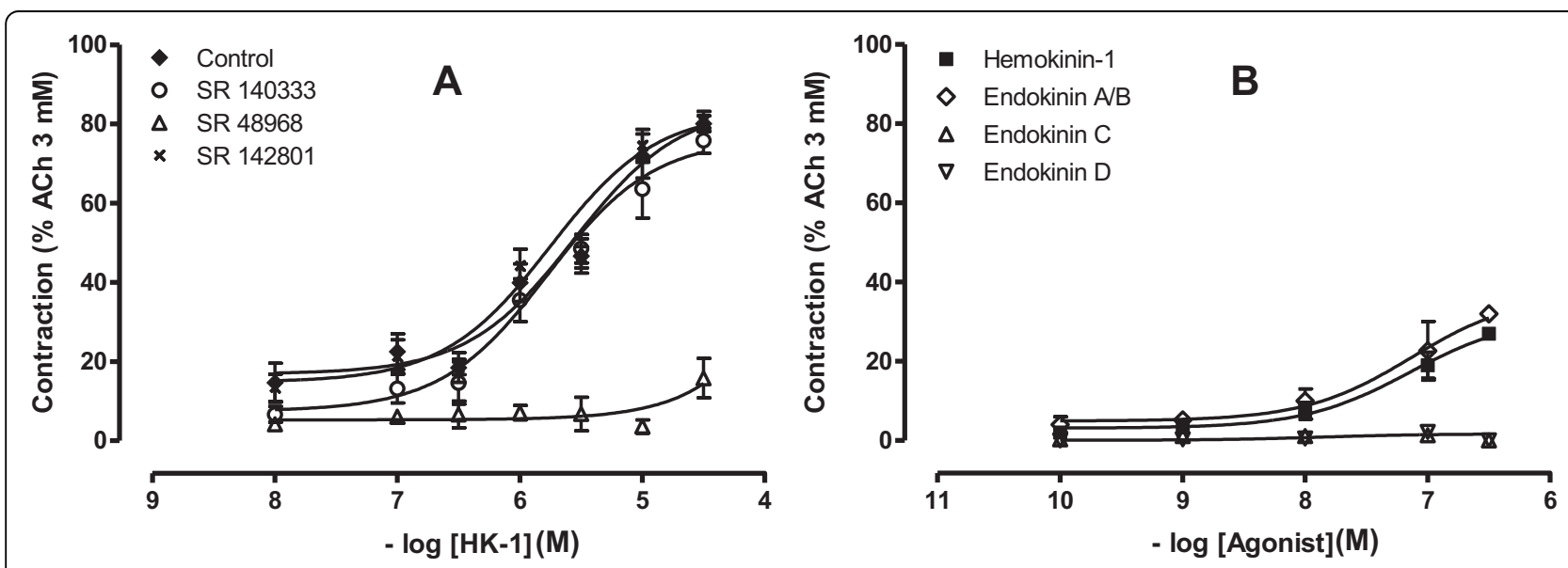

Figure 2 (A) Cumulative concentration-response curves of hHK-1 on human bronchi $(n=5-12)$ in the absence (control) and presence of $\mathrm{NK}_{1}, \mathrm{NK}_{2}$ or $\mathrm{NK}_{3}$ receptor antagonists SR 140333, SR 48968 or SR $142801\left(10^{-7} \mathrm{M}\right)$. (B) Cumulative concentration-response curves of hHK-1, EKA/B, EKC and EKD on human bronchi $(n=3)$. Experiments were performed in the presence of phosphoramidon $\left(10^{-6} \mathrm{M}\right)$. Values are expressed in percentage (mean \pm s.e.m.) of maximal contraction obtained with ACh $3 \mathrm{mM}$. 


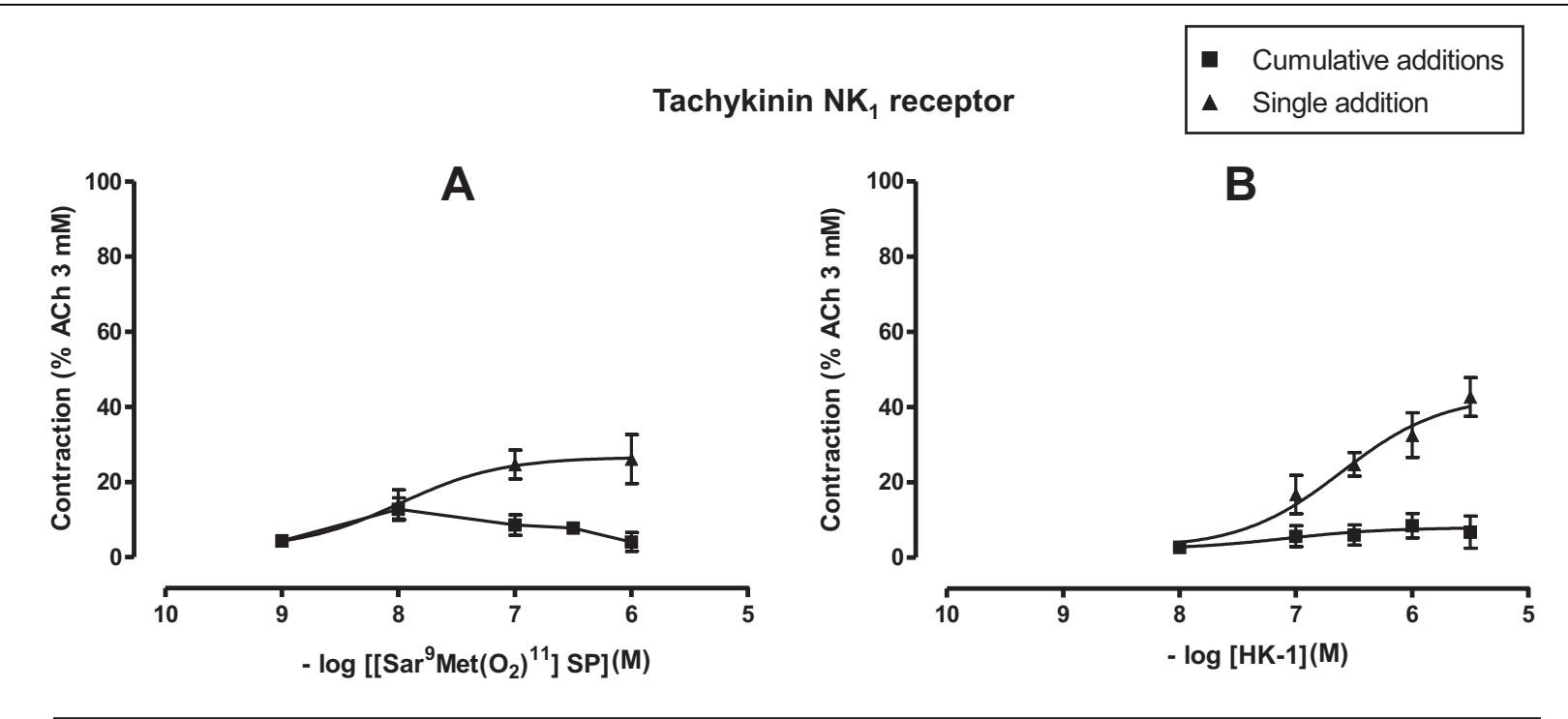

Tachykinin $\mathrm{NK}_{2}$ receptor
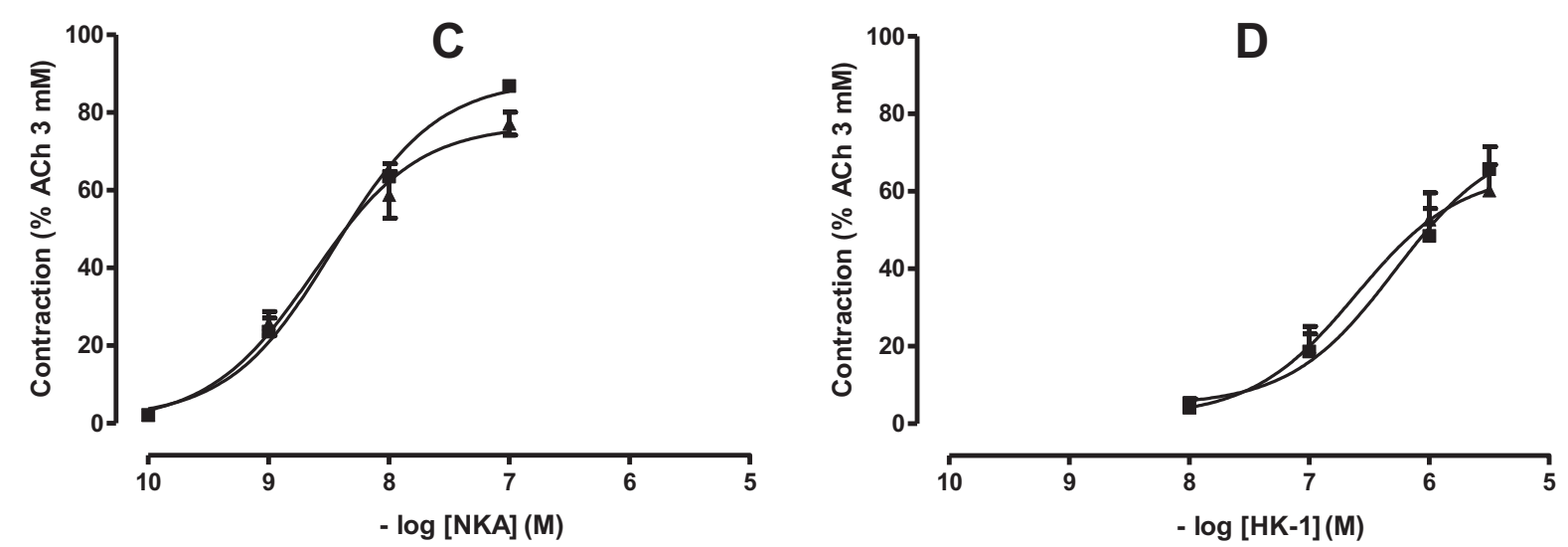

Figure 3 Desensitization of tachykinin $\mathbf{N K}_{\mathbf{1}}(\mathbf{A}$ and $\mathbf{B})$ and $\mathbf{N K}_{\mathbf{2}}$ (C and D) receptors. Human bronchi were pre-treated with SR $48968\left(10^{-7} \mathrm{M}\right)$ ( $A$ and $B)$ or SR $140333\left(10^{-7} \mathrm{M}\right)(C$ and D) before cumulative or non cumulative additions of hHK-1 (B and $D, n=5),\left[\operatorname{Sar}^{9}, \operatorname{Met}\left(\mathrm{O}_{2}\right)^{11}\right]$ SP $(A, n=10)$ or NKA $(C, n=5)$. Experiments were performed in the presence of phosphoramidon $\left(10^{-6} \mathrm{M}\right)$. Values are expressed in percentage (mean \pm s.e.m.) of maximal contraction obtained with ACh $3 \mathrm{mM}$.

Cross-desensitization of tachykinin $\mathrm{NK}_{1}$ receptor between hHK-1 and $\left[\mathrm{Sar}^{9}, \operatorname{Met}\left(\mathrm{O}_{2}\right)^{11}\right] \mathrm{SP}$

Since $\left[\operatorname{Sar}^{9}, \operatorname{Met}\left(\mathrm{O}_{2}\right)^{11}\right]$ SP and hHK-1 are both able to induce a desensitization of $\mathrm{NK}_{1}$ receptors, we performed cross-desensitization experiments with the two compounds in order to assess if tissues desensitized with one peptide were still responsive to a subsequent addition of the other peptide. Fig. 5 shows that after an initial contraction induced by a single addition of [ $\mathrm{Sar}^{9}$, $\operatorname{Met}\left(\mathrm{O}_{2}\right)^{11}$ ] SP $\left(10^{-7} \mathrm{M}\right)$, the response to a second addition of this peptide was abolished $(33 \pm 7 \%$ for the first addition, $4 \pm 1 \%$ for the second, $n=5, p<0.01)$, whereas under similar conditions, after an initial addition of $\left[\mathrm{Sar}^{9}, \mathrm{Met}\left(\mathrm{O}_{2}\right)^{11}\right] \mathrm{SP}$, the response to hHK-1 $\left(3.10^{-7} \mathrm{M}\right)$ was maintained $(32 \pm 7 \%$ and $34 \pm 5 \%$ respectively, $n=5)$. When hHK-1 was added in a first step to the bath, the response to $\left[\operatorname{Sar}^{9}, \operatorname{Met}\left(\mathrm{O}_{2}\right)^{11}\right] \mathrm{SP}$ was abolished, whereas the response to a second addition of hHK-1 itself was partially reduced ( $48 \pm 8 \%$ and $30 \pm 2 \%$ respectively, $n=5$ ), suggesting a cross-desensitization between $\mathrm{hHK}-1$ and $\left[\operatorname{Sar}^{9}, \operatorname{Met}\left(\mathrm{O}_{2}\right)^{11}\right]$ SP for the $\mathrm{NK}_{1}$ receptor.

\section{Characterization of hHK-1- and endokinins-induced responses in guinea pig airways Contractile effects of hHK-1 and endokinins in isolated guinea pig airways}

Human hemokinin-1 induced concentration-dependent contractions of the guinea-pig trachea (fig. 6A). This effect was reproducible and independent of the protocol 

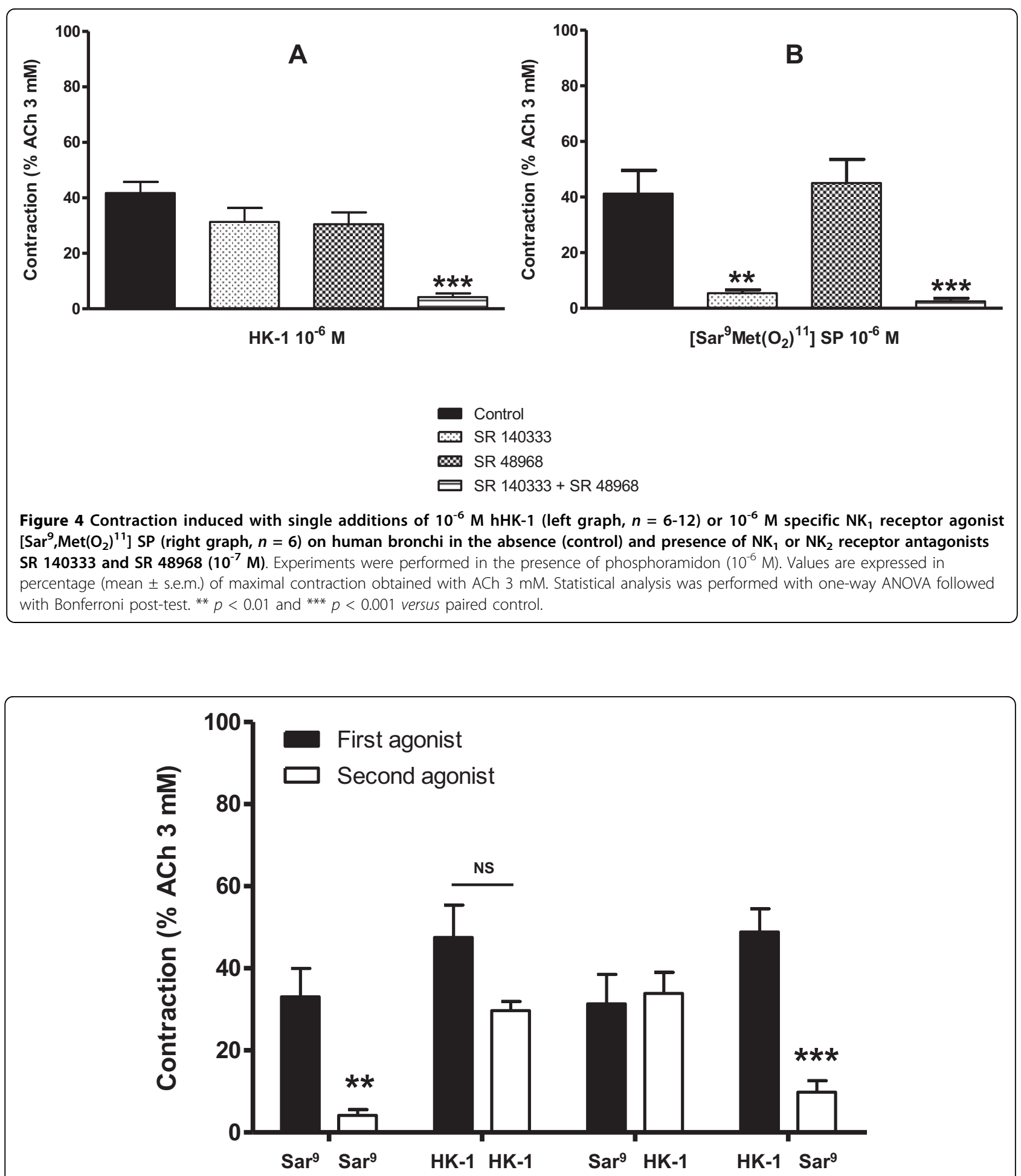

Figure 5 Cross-desensitization of $\mathrm{NK}_{1}$ receptors after consecutive applications of hHK-1 $\left(3.10^{-7} \mathrm{M}\right)$ and $\left[\mathrm{Sar}^{9}, \mathrm{Met}\left(\mathrm{O}_{2}\right)^{11}\right] \mathrm{SP}\left(10^{-7} \mathrm{M}\right)$ on human bronchi $(\boldsymbol{n}=\mathbf{5})$. All combinations of $\mathrm{hHK}-1$ and $\left[\mathrm{Sar}^{9}, \operatorname{Met}\left(\mathrm{O}_{2}\right)^{11}\right]$ SP were assessed. Experiments were performed in the presence of phosphoramidon $\left(10^{-6} \mathrm{M}\right.$ ). Values are expressed in percentage (mean \pm s.e.m.) of maximal contraction obtained with ACh $3 \mathrm{mM}$. Statistical analysis was performed with two-way ANOVA for repeated measures followed with Bonferroni post-test. ** $p<0.01$ and ${ }^{* * *} p<0.001$ for contraction obtained after the second application versus the first application. $\left(\operatorname{Sar}^{9}=\left[\operatorname{Sar}^{9}, \operatorname{Met}\left(\mathrm{O}_{2}\right)^{11}\right] \mathrm{SP}\right)$. 


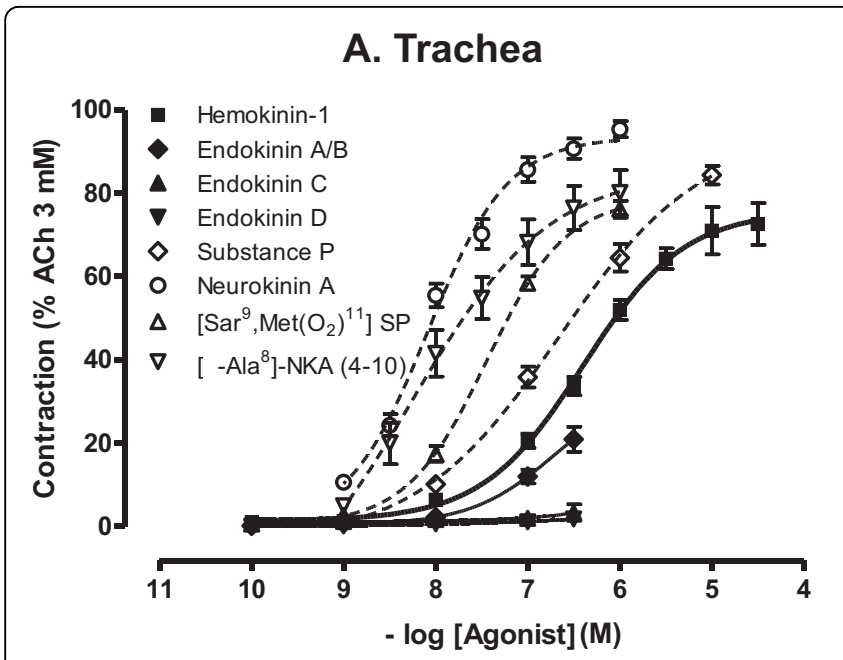

\section{B. Main bronchi}

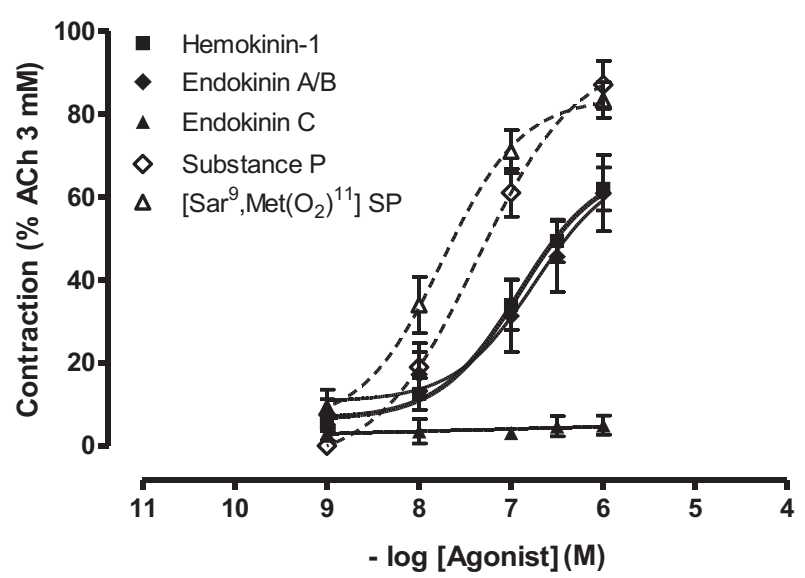

Figure 6 Concentration-response curves to (A) cumulative additions of hHK-1, EKA/B, EKC, EKD, SP, NKA and specific NK ${ }_{1}\left(\left[\mathrm{Sar}^{9},{ }^{9} \mathrm{Met}\left(\mathrm{O}_{2}\right)^{11}\right] \mathrm{SP}\right)$ and $\mathrm{NK}_{2}\left(\left[\beta-\mathrm{Ala}^{8}\right]\right.$-NKA (4-10)) receptor agonists on guinea pig trachea $(n=6-12)$; (B) cumulative additions of hHK-1, EKA/B, EKC, SP and $\left[\mathrm{Sar}^{9}, \mathrm{Met}\left(\mathrm{O}_{2}\right)^{11}\right] \mathrm{SP}$ on guinea pig main bronchi $(\boldsymbol{n}=6-7)$. Experiments were performed in the presence of phosphoramidon $\left(10^{-6} \mathrm{M}\right)$. Values are expressed in percentage (mean \pm s.e.m.) of maximal contraction obtained with ACh $3 \mathrm{mM}$.

used for the addition of hHK-1 (cumulative or noncumulative). Table 1 shows that hHK-1 potency was similar to that of SP, but was 11 -fold lower than that of $\left[\mathrm{Sar}^{9}, \mathrm{Met}\left(\mathrm{O}_{2}\right)^{11}\right]$ SP and 49- and 72-fold lower than that of the $\mathrm{NK}_{2}$-receptor agonists, NKA and $\left[\beta-\mathrm{Ala}^{8}\right]$-NKA (4-10), respectively. EKA/B $\left(10^{-8} \mathrm{M}-10^{-6} \mathrm{M}\right)$ exerted similar effects to hHK-1, whereas EKC and EKD were without effect (fig. 6A). In guinea-pig isolated bronchi (fig. 6B), hHK-1 and EKA/B exerted similar effects but were less potent than SP and $\left[\operatorname{Sar}^{9}, \operatorname{Met}\left(\mathrm{O}_{2}\right)^{11}\right]$ SP.

Effects of tachykinin receptor antagonists on cumulative additions of hHK-1 to guinea pig airways

Contractions induced by hHK-1 on the isolated guineapig trachea (fig. 7A and 7B) and main bronchi (fig. 7C) were abolished by the $\mathrm{NK}_{1}$ receptor antagonist SR

Table 1 Functional potencies and maximal effects of human hemokinin-1 and various tachykinin peptides on guinea-pig trachea

\begin{tabular}{|c|c|c|c|}
\hline Agonist & $N$ & $\mathrm{pD}_{2}$ & $E_{\max }(\%$ of $A c h 3 \mathrm{mM})$ \\
\hline$\overline{\mathrm{hHK}-1}$ & 12 & $6.4 \pm 0.03$ & $73 \pm 5$ \\
\hline $\mathrm{EKA} / \mathrm{B}$ & 6 & ND & ND \\
\hline SP & 12 & $6.7 \pm 0.1$ & $84 \pm 2$ \\
\hline$\left[\operatorname{Sar}^{9}, \operatorname{Met}\left(\mathrm{O}_{2}\right)^{11}\right] \mathrm{SP}$ & 12 & $7.5 \pm 0.1$ & $76 \pm 2$ \\
\hline NKA & 6 & $8.1 \pm 0.1$ & $95 \pm 2$ \\
\hline$\left[\beta\right.$-Ala $\left.{ }^{8}\right]-N K A(4-10)$ & 6 & $8.3 \pm 0.6$ & $80 \pm 5$ \\
\hline
\end{tabular}

hHK-1: human hemokinin-1, EKA/B: endokinin A/B, SP: substance P, NKA: neurokinin A.

ND: not determined because an asymptote was not reached with the highest concentration $(1 \mu \mathrm{M})$ applied.

Values are presented as $\mathrm{pD}_{2}$ and percentage of maximal contraction obtained with Ach $3 \mathrm{mM}$ (mean \pm s.e.m.) for $n$ determinations. $140333\left(10^{-7} \mathrm{M}\right)$, and were altered to a lesser extent by the $\mathrm{NK}_{2}$ receptor antagonist SR $48968\left(10^{-7} \mathrm{M}\right)$. In addition, fig. 7A shows that SR 140333 reduced maximal contractions induced by hHK-1 in the guinea-pig trachea, suggesting a non competitive antagonism in line with previous data on the rabbit pulmonary artery and on the guinea pig ileum [42].

\section{Effects of hHK-1 and SP on cytokine production by} human bronchi or lung parenchyma explants and by lung macrophages

hHK-1 and SP up to $10^{-5} \mathrm{M}$ had no impact on TNF- $\alpha$, IL8 and MIP- $1 \alpha$ production by bronchial explants $(n=4)$. Similarly, both peptides did not alter TNF- $\alpha$, IL-6, MIP$1 \alpha$, MCP-1, ENA-78, GRO- $\alpha$, MIG, and MIF production by lung parenchyma ( $n=6$ different preparations) and TNF- $\alpha$, IL- 6 , MIF, MIG and MIP- $1 \alpha$ production by lung macrophages ( $n=3$ to 6 different preparations) (data not shown). LPS caused a clear-cut increase of these cytokines in all preparations.

\section{Discussion}

In the present study we have demonstrated the expression of TAC4 transcript and protein in human bronchi and shown that hHK-1 and EKA/B exert a contractile effect in human and guinea pig airways. In human isolated bronchi, the response is mediated mainly through $\mathrm{NK}_{2}$ receptor stimulation, the $\mathrm{NK}_{1}$ receptor-mediated effect being unmasked in the presence of SR 48968 and subject to rapid desensitization. In guinea pig trachea and main bronchi, the response is mediated mainly through $\mathrm{NK}_{1}$ receptor stimulation and to a minor extent 


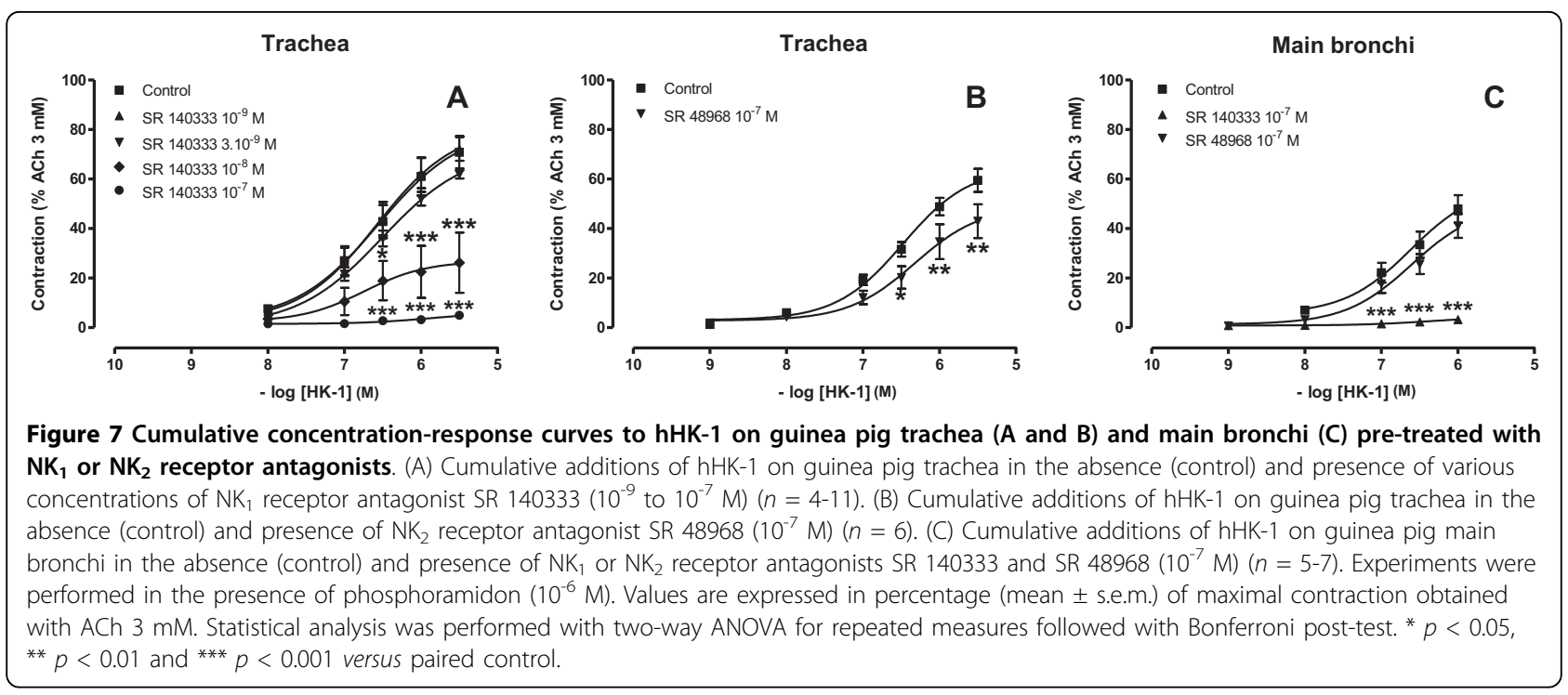

through $\mathrm{NK}_{2}$ receptors. The $\mathrm{N}$-terminally extended form of human hHK-1, EKA/B, exerts similar effects to hHK1 on both human bronchi and guinea pig airways, whereas EKC and EKD, peptides also derived from $T A C 4$, did not induce functional responses. Finally, we have shown that hHK-1 did not alter cytokine production by human bronchi or parenchyma explants, or by human lung macrophages.

Our study shows that the TAC4 gene encoding for hHK- 1 is constitutively present and expressed in human airways. Only a few numbers of studies have been devoted to the presence of TAC4 in human tissues, particularly in lung, and none of them has previously reported expression of hHK-1 protein. Indeed, TAC4 expression was not found in the mouse lung by northern blot analysis [3], but was demonstrated by semi-quantitative PCR in murine lung (mouse, gerbil) $[4,5]$. In human, a wide expression of TAC4 has been reported with a strong expression in tissues such as heart, skeletal muscle, skin, thyroid, spinal cord, placenta, adrenal gland, spermatozoa and blood circulating cells and a weaker expression in whole lung, kidney, testis and liver $[4,6,39,47]$. In contrast to $T A C 4$, we have shown that TAC1, which encodes for SP and NKA, was not detected under our experimental conditions and that TAC3 was observed in only one of four samples. In a previous study, Pinto et al. showed in a human total mRNA master panel (BD Biosciences Clontech) that TAC1 and TAC3 mRNAs were undetectable in the lung, but they observed a low expression of these transcripts in samples of human bronchi obtained from patients who had undergone lobectomy or pneumectomy for lung carcinoma, a high expression being observed in pulmonary arteries [48]. Concerning the genes that encode for tachykinin receptors, we have identified the mRNA expression of TACR1 $\left(\mathrm{NK}_{1}\right.$ receptor) and TACR2 ( $\mathrm{NK}_{2}$ receptor), in agreement with Pinto et al. and in agreement with previous immunohistochemical evidences of $\mathrm{NK}_{1}$ and $\mathrm{NK}_{2}$ receptor expressions in human bronchial smooth muscle, bronchial glands and bronchial vessels $[48,49]$. We did not find TACR3 $\left(\mathrm{NK}_{3}\right.$ receptor) expression whereas Pinto et al. identified this transcript in all assayed tissues [48]. These discrepancies in the results of tachykinin transcript expression could be related to differences either within human samples or to differences in expression patterns of tachykinin genes along the respiratory tract since we used smaller bronchi than in the work of Pinto et al. and since differences in the response to tachykinins have been reported according to the size of human bronchi [22]. It should be noted that we found TAC4 transcript and hHK-1 protein expressions in human bronchi similar in size (1 to $3 \mathrm{~mm}$ ) to the bronchi used for the functional studies, substantiating a role for hHK-1 in the regulation of airway tone. Finally, our results showing NEP mRNA expression are also consistent with previous studies reporting a strong expression of NEP in human bronchi [50].

In human isolated bronchi pre-treated with phosphoramidon, hHK-1 exerts a contractile effect which was abolished by the $\mathrm{NK}_{2}$ receptor antagonist SR 48968, while the $\mathrm{NK}_{1}$ receptor antagonist SR 140333 only weakly reduced the effects of hHK-1 at low concentrations. In human bronchi, hHK-1 appears 800 -fold less potent than NKA. This result is in agreement with previous data obtained on $\mathrm{NK}_{2}$ receptors either with $\mathrm{CHO}$ cells [4] or rabbit pulmonary artery [13].

A rapid functional desensitization of $\mathrm{NK}_{1}$ receptors has been reported with $\mathrm{SP}$ and specific $\mathrm{NK}_{1}$ receptor agonists in different tissues [51,52] including airways [22]. In addition, HK-1 has been reported to induce a desensitization of $\mathrm{NK}_{1}$ receptors in human embryonic 
kidney cells [11], rabbit jugular veins [13], U251 MG astrocytoma cells [53] and scratching behavior in rats [54]. We also observed desensitization of $\mathrm{NK}_{1}$ receptors in human bronchi, since the magnitude of the contractile response caused by the second application of the $\mathrm{NK}_{1}$-receptor specific agonist was lower than after the first addition, even with a 10-fold higher concentration. Such a desensitization can be due to receptor internalization, which is a common phenomenon for $\mathrm{NK}_{1}$ receptor signaling [55] and has already been described with hHK-1 on astrocytoma cells [53]. We have demonstrated a cross-desensitization between hHK-1 and $\left[\operatorname{Sar}^{9}\right.$, Met $\left.\left(\mathrm{O}_{2}\right)^{11}\right]$ SP substantiating $\mathrm{NK}_{1}$-receptor activation and desensitization by hHK-1. In addition, since a first exposure to $\left[\mathrm{Sar}^{9}\right.$, Met $\left.\left(\mathrm{O}_{2}\right)^{11}\right]$ SP was able to desensitize the $\mathrm{NK}_{1}$ receptor, preventing a second response to this specific $\mathrm{NK}_{1}$-receptor agonist, but was unable to prevent the response to hHK-1, these crossdesensitization experiments further substantiate the $\mathrm{NK}_{2}$-receptor mediated component of the contractile response to hHK-1. As expected in the single addition protocol, the contractile effect of $\left[\mathrm{Sar}^{9}, \operatorname{Met}\left(\mathrm{O}_{2}\right)^{11}\right] \mathrm{SP}$ was abolished by the $\mathrm{NK}_{1}$ receptor antagonist SR 140333 and unmodified by the $\mathrm{NK}_{2}$ receptor antagonist SR 48968. In contrast, the effect of hHK-1 was not inhibited by SR 140333 or SR 48968 when used alone, but was abolished by concomitant addition of the two antagonists, demonstrating that hHK-1 contracts bronchi through $\mathrm{NK}_{1}$ - and $\mathrm{NK}_{2}$ receptors. However, it can also be suggested that $\left[\operatorname{Sar}^{9}, \operatorname{Met}\left(\mathrm{O}_{2}\right)^{11}\right]$ SP and SP on the one hand, and hHK-1 on the other hand, may bind to different sites of the $\mathrm{NK}_{1}$ receptor and interact in a different manner with receptor antagonists $[5,56]$.

In contrast with the results in human bronchi, SP and the specific $\mathrm{NK}_{1}$-receptor agonist produced maximal responses similar to those of NKA and hHK-1 in guinea pig airways providing evidence of the higher involvement of $\mathrm{NK}_{1}$ receptors in this animal species than in humans as already reported [23,40]. In support of this notion, hHK-1 exerted a contractile effect mainly through $\mathrm{NK}_{1}$ receptor stimulation since this effect was abolished by the $\mathrm{NK}_{1}$ receptor antagonist SR 140333, but was only weakly reduced in the presence of the $\mathrm{NK}_{2}$ receptor antagonist SR 48968. However, the $\mathrm{NK}_{2}$ receptors play a predominant role in guinea pig airways contraction since NKA is approximately 10 -fold more potent than SP $[23,40]$. The weak effect of SR 48968 against hHK-1 induced bronchoconstriction in the guinea pig airways is likely explained by the higher affinity of hHK-1 for $\mathrm{NK}_{1}$ - than for $\mathrm{NK}_{2}$ receptors in a preparation fully responsive to $\mathrm{NK}_{1}$-mediated response $[4,10,13]$. It is noteworthy that the potency of hHK-1 in the guinea pig airways was lower than that reported for $\mathrm{r} / \mathrm{mHK}-1$ in specific $\mathrm{NK}_{1}$-receptor animal tissues such as rabbit jugular vein [13], rat urinary bladder [10] and pig coronary artery [17].

In our study of cytokines production, we were not able to reproduce the weak TNF- $\alpha$ production that was observed in SP-stimulated human alveolar macrophages from healthy subjects [57]. This result may be related to the underlying disease or the smoking status of the patients that were all ex-smokers in our study since SPinduced TNF- $\alpha$ release is more pronounced in smokers [57]. SP-induced release of inflammatory mediators by human monocytes/macrophages still remains controversial and may have been related to the presence of endotoxin at low levels [58-61]. In addition to the lung macrophages, explants of lung parenchyma and bronchi did not produce pro-inflammatory cytokines in response to hHK-1 or SP, suggesting that hHK-1 may not be involved in lung inflammatory pathways through the release of these cytokines. However, hHK-1 may exert other inflammatory effects as already described for SP or NKA (reviewed in [36]).

SP expression has been reported in the human respiratory tract [62] and is increased in airways [63], bronchoalveolar or nasal lavages [64], sputum [65] or plasma [66] from asthmatics. It has been demonstrated that the antibodies used in such studies were directed against the C-terminal portion of SP, which is shared by hHK-1, leading to cross-reactivity with hHK-1 [5]. Immunoreactivity attributed to SP expression in human lungs may therefore be also related to hHK-1 expression. The use of specific assays for hHK-1 is required to evaluate the respective expression of SP and hHK-1 in the respiratory tracts of healthy subjects and in patients with asthma.

\section{Conclusion}

In conclusion, our results provide evidence for a constitutive expression of TAC4 and hHK-1 in human bronchi. Our findings indicate that hHK-1 could induce contraction of human bronchi and guinea pig airways. This hHK-1-induced contraction could be mainly attributed to $\mathrm{NK}_{2}$ receptors in humans and to $\mathrm{NK}_{1}$ receptors in guinea pig. The absence cytokine release from lung explants and macrophages suggests that hHK-1 does not participate in airways inflammation by inducing the release of the pattern of cytokines measured in the present study. hHK-1 is therefore involved in the tachykinin-driven contractile response of human airways, but further studies are needed for a better understanding of hHK-1 involvement in airway diseases such as asthma.

\section{Author details}

${ }^{1}$ Laboratory of pulmonary pharmacology UPRES EA220, Foch Hospital, University Versailles-Saint Quentin en Yvelines, 11 rue Guillaume Lenoir, 92150 Suresnes, France. ${ }^{2}$ Meakins-Christie Laboratories, Department of 
Medicine, McGill University, Montreal, QC, Canada. ${ }^{3}$ Department of thoracic surgery, Foch Hospital, University Versailles-Saint Quentin en Yvelines, 40 rue worth, 92150 Suresnes, France.

\section{Authors' contributions}

SGD carried out the molecular genetic studies, the contractile function studies, the cultures of lung explants, the immunoassays, participated to the interpretation of data, performed the statistical analysis and drafted the manuscript. EN participated to the contractile function studies and to the analysis and interpretation of data. AB and PAR participated to the cultures of lung explants ant to the immunoassays. ES provided human tissues and critically revised the manuscript. CA and PD conceived the study, participated in its design and coordination and drafted the manuscript. All authors read and approved the final manuscript.

\section{Competing interests}

The authors declare that they have no competing interests.

Received: 16 April 2010 Accepted: 7 October 2010

Published: 7 October 2010

\section{References}

1. Kotani H, Hoshimaru M, Nawa H, Nakanishi S: Structure and gene organization of bovine neuromedin K precursor. Proc Natl Acad Sci USA 1986, 83(18):7074-7078.

2. Page NM, Woods RJ, Lowry PJ: A regulatory role for neurokinin B in placental physiology and pre-eclampsia. Regul Pept 2001, 98(3):97-104.

3. Zhang Y, Lu L, Furlonger C, Wu GE, Paige CJ: Hemokinin is a hematopoietic-specific tachykinin that regulates $B$ lymphopoiesis. Nat Immunol 2000, 1(5):392-397.

4. Kurtz MM, Wang R, Clements MK, Cascieri MA, Austin CP, Cunningham BR, Chicchi GG, Liu Q: Identification, localization and receptor characterization of novel mammalian substance P-like peptides. Gene 2002, 296(1-2):205-212.

5. Page NM: Hemokinins and endokinins. Cell Mol Life Sci 2004 61(13):1652-1663.

6. Page NM, Bell NJ, Gardiner SM, Manyonda IT, Brayley KJ, Strange PG, Lowry PJ: Characterization of the endokinins: human tachykinins with cardiovascular activity. Proc Natl Acad Sci USA 2003, 100(10):6245-6250.

7. Almeida TA, Rojo J, Nieto PM, Pinto FM, Hernandez M, Martin JD, Candenas ML: Tachykinins and tachykinin receptors: structure and activity relationships. Curr Med Chem 2004, 11(15):2045-2081.

8. Maggi CA: The mammalian tachykinin receptors. Gen Pharmacol 1995, 26(5):911-944.

9. Regoli D, Boudon A, Fauchere JL: Receptors and antagonists for substance $P$ and related peptides. Pharmacol Rev 1994, 46(4):551-599.

10. Bellucci F, Carini F, Catalani C, Cucchi P, Lecci A, Meini S, Patacchini R, Quartara L, Ricci R, Tramontana M, et al: Pharmacological profile of the novel mammalian tachykinin, hemokinin 1. Br J Pharmacol 2002, 135(1):266-274.

11. Morteau O, Lu B, Gerard C, Gerard NP: Hemokinin 1 is a full agonist at the substance $P$ receptor. Nat Immunol 2001, 2(12):1088.

12. Duffy RA, Hedrick JA, Randolph G, Morgan CA, Cohen-Williams ME, Vassileva G, Lachowicz JE, Laverty M, Maguire M, Shan LS, et al: Centrally administered hemokinin-1 (HK-1), a neurokinin NK1 receptor agonist, produces substance P-like behavioral effects in mice and gerbils. Neuropharmacology 2003, 45(2):242-250

13. Camarda V, Rizzi A, Calo G, Guerrini R, Salvadori S, Regoli D: Pharmacological profile of hemokinin 1: a novel member of the tachykinin family. Life Sci 2002, 71(4):363-370.

14. Metwali A, Blum AM, Elliott DE, Setiawan T, Weinstock JV: Cutting edge: hemokinin has substance P-like function and expression in inflammation. J Immunol 2004, 172(11):6528-6532.

15. Zhang Y, Paige CJ: T-cell developmental blockage by tachykinin antagonists and the role of hemokinin 1 in T lymphopoiesis. Blood 2003, 102(6):2165-2172.

16. Weinstock $\mathrm{JV}$ : The role of substance $P$, hemokinin and their receptor in governing mucosal inflammation and granulomatous responses. Front Biosci 2004, 9:1936-1943.

17. Long Y, Fu CY, Tian XZ, Chen J, Han M, Wang R: Mechanisms of relaxing response induced by rat/mouse hemokinin-1 in porcine coronary arteries: roles of potassium ion and nitric oxide. Eur J Pharmacol 2007, 569(1-2):119-125.

18. Patak E, Pennefather JN, Gozali M, Candenas L, Kerr K, Exintaris B, Ziccone S, Potteck $\mathrm{H}$, Chetty N, Page NM, et al: Functional characterisation of hemokinin-1 in mouse uterus. Eur J Pharmacol 2008, 601(1-3):148-53.

19. Pennefather JN, Patak E, Ziccone S, Lilley A, Pinto FM, Page NM, Story ME, Grover S, Candenas ML: Regulation of the Stimulant Actions of Neurokinin A and Human Hemokinin-1 on Human Uterus: a Comparison with Histamine. Biol Reprod 2006, 75(3):334-41.

20. Kong ZQ, Yang WL, Tao Y, Shi XM, Fu CY, Zhao RF, Wang R: Effects of rat/ mouse hemokinin-1, human hemokinin-1 and human hemokinin-1(411), mammalian tachykinin peptides, on rate and perfusion pressure in the isolated guinea pig heart. Neuropeptides 2010, 44(5):437-44.

21. Naline E, Devillier P, Drapeau G, Toty L, Bakdach H, Regoli D, Advenier C: Characterization of neurokinin effects and receptor selectivity in human isolated bronchi. Am Rev Respir Dis 1989, 140(3):679-686.

22. Naline E, Molimard M, Regoli D, Emonds-Alt X, Bellamy JF, Advenier C: Evidence for functional tachykinin NK1 receptors on human isolated small bronchi. Am J Physiol 1996, 271(5 Pt 1):L763-767.

23. Advenier C, Naline E, Drapeau G, Regoli D: Relative potencies of neurokinins in guinea pig trachea and human bronchus. Eur J Pharmacol 1987, 139(2):133-137

24. Lundberg JM, Martling CR, Saria A: Substance $P$ and capsaicin-induced contraction of human bronchi. Acta Physiol Scand 1983, 119(1):49-53.

25. Frossard N, Barnes J: Effect of tachykinins in small human airways. Neuropeptides 1991, 19(3):157-161.

26. Girard V, Feletou M, Advenier C, Canet E: Effects of tachykinins and capsaicin on the mechanical and electrical activity of the guinea-pig isolated trachea. Br J Pharmacol 1997, 122(5):841-848.

27. Groneberg DA, Quarcoo D, Frossard N, Fischer A: Neurogenic mechanisms in bronchial inflammatory diseases. Allergy 2004, 59(11):1139-1152.

28. Heaney LG, Cross LJ, Stanford CF, Ennis M: Substance P induces histamine release from human pulmonary mast cells. Clin Exp Allergy 1995 25(2):179-186.

29. Wiedermann FJ, Kahler CM, Reinisch N, Wiedermann CJ: Induction of normal human eosinophil migration in vitro by substance $P$. Acta Haematol 1993, 89(4):213-215.

30. Carolan EJ, Casale TB: Effects of neuropeptides on neutrophil migration through noncellular and endothelial barriers. J Allergy Clin Immunol 1993, 92(4):589-598.

31. Iwamoto I, Nakagawa N, Yamazaki H, Kimura A, Tomioka H, Yoshida S: Mechanism for substance P-induced activation of human neutrophils and eosinophils. Regul Pept 1993, 46(1-2):228-230.

32. Schratzberger $P$, Reinisch N, Prodinger WM, Kahler CM, Sitte BA, Bellmann R, Fischer-Colbrie R, Winkler $\mathrm{H}$, Wiedermann CJ: Differential chemotactic activities of sensory neuropeptides for human peripheral blood mononuclear cells. J Immunol 1997, 158(8):3895-3901.

33. Boichot $E$, Lagente $V$, Paubert-Braquet $M$, Frossard $N$ : Inhaled substance $P$ induces activation of alveolar macrophages and increases airway responses in the guinea-pig. Neuropeptides 1993, 25(5):307-313.

34. Nelson DA, Bost KL: Non-neuronal mammalian tachykinin expression. Front Biosci 2004, 9:2166-2176.

35. Pennefather JN, Lecci A, Candenas ML, Patak E, Pinto FM, Maggi CA Tachykinins and tachykinin receptors: a growing family. Life Sci 2004, 74(12):1445-1463.

36. Maggi CA: The effects of tachykinins on inflammatory and immune cells. Regul Pept 1997, 70(2-3):75-90.

37. Ben-Jebria A, Marthan R, Rossetti M, Savineau JP: Effect of passive sensitization on the mechanical activity of human isolated bronchial smooth muscle induced by substance $\mathrm{P}$, neurokinin $\mathrm{A}$ and VIP. $\mathrm{Br} J$ Pharmacol 1993, 109(1):131-136.

38. Yoshioka D, Takebuchi F, Nishimori T, Naono R, Ikeda T, Nakayama T: Intrathecal administration of the common carboxyl-terminal decapeptide in endokinin $A$ and endokinin $B$ evokes scratching behavior and thermal hyperalgesia in the rat. Neurosci Lett 2006 , 410(3):193-197.

39. Ravina CG, Seda M, Pinto FM, Orea A, Fernandez-Sanchez M, Pintado CO, Candenas ML: A role for tachykinins in the regulation of human sperm motility. Hum Reprod 2007, 22(6):1617-1625

40. Devillier P, Advenier C, Drapeau G, Marsac J, Regoli D: Comparison of the effects of epithelium removal and of an enkephalinase inhibitor on the 
neurokinin-induced contractions of guinea-pig isolated trachea. $\mathrm{Br} J$ Pharmacol 1988, 94(3):675-684.

41. Emonds-Alt X, Bichon D, Ducoux JP, Heaulme M, Miloux B, Poncelet M, Proietto V, Van Broeck D, Vilain P, Neliat G, et al: SR 142801, the first potent non-peptide antagonist of the tachykinin NK3 receptor. Life Sci 1995, 56(1):PL27-32.

42. Emonds-Alt X, Doutremepuich JD, Heaulme M, Neliat G, Santucci V, Steinberg R, Vilain P, Bichon D, Ducoux JP, Proietto V, et al: In vitro and in vivo biological activities of SR140333, a novel potent non-peptide tachykinin NK1 receptor antagonist. Eur J Pharmacol 1993, 250(3):403-413.

43. Emonds-Alt $X$, Vilain $P$, Goulaouic $P$, Proietto $V$, Van Broeck D, Advenier $C$, Naline E, Neliat G, Le Fur G, Breliere JC: A potent and selective nonpeptide antagonist of the neurokinin A (NK2) receptor. Life Sci 1992, 50(15):PL101-106.

44. Berger A, Tran AH, Paige CJ: Co-regulated decrease of Neurokinin-1 receptor and Hemokinin-1 gene expression in monocytes and macrophages after activation with pro-inflammatory cytokines. $J$ Neuroimmunol 2007, 187(1-2):83-93.

45. Mitsuta K, Shimoda T, Fukushima C, Obase Y, Ayabe H, Matsuse H, Kohno S: Preoperative steroid therapy inhibits cytokine production in the lung parenchyma in asthmatic patients. Chest 2001, 120(4):1175-1183.

46. Buenestado A, Grassin Delyle S, Arnould I, Besnard F, Naline E, BlouquitLaye S, Chapelier A, Bellamy JF, Devillier P: The role of adenosine receptors in regulating production of tumour necrosis factor-alpha and chemokines by human lung macrophages. Br J Pharmacol 2010, 159(6):1304-1311.

47. Klassert TE, Pinto F, Hernandez M, Candenas ML, Hernandez MC, Abreu J, Almeida TA: Differential expression of neurokinin B and hemokinin-1 in human immune cells. J Neuroimmunol 2008, 196(1-2):27-34.

48. Pinto FM, Almeida TA, Hernandez M, Devillier P, Advenier C, Candenas ML: mRNA expression of tachykinins and tachykinin receptors in different human tissues. Eur J Pharmacol 2004, 494(2-3):233-239.

49. Mapp CE, Miotto D, Braccioni F, Saetta M, Turato G, Maestrelli P, Krause JE, Karpitskiy V, Boyd N, Geppetti P, et al: The distribution of neurokinin-1 and neurokinin-2 receptors in human central airways. Am J Respir Crit Care Med 2000, 161(1):207-215.

50. Baraniuk JN, Ohkubo K, Kwon OJ, Mak J, Ali M, Davies R, Twort C, Kaliner M, Letarte $\mathrm{M}$, Barnes PJ: Localization of neutral endopeptidase (NEP) mRNA in human bronchi. Eur Respir J 1995, 8(9):1458-1464.

51. Culman J, Tschope $C$, Jost N, Itoi K, Unger T: Substance $P$ and neurokinin A induced desensitization to cardiovascular and behavioral effects: evidence for the involvement of different tachykinin receptors. Brain Res 1993, 625(1):75-83.

52. Nakanishi S: Mammalian tachykinin receptors. Annu Rev Neurosci 1991, 14:123-136.

53. Berger A, Paige CJ: Hemokinin-1 has Substance P-like function in U-251 MG astrocytoma cells: a pharmacological and functional study. $J$ Neuroimmunol 2005, 164(1-2):48-56.

54. Naono R, Yoshioka D, Ikeda T, Nakayama T, Nishimori T: The common carboxyl-terminal region of novel tachykinin peptides contributes to induce desensitization in scratching behavior of rats. Brain Res Bull 2007, 71(5):461-465.

55. Hokfelt T, Pernow B, Wahren J: Substance P: a pioneer amongst neuropeptides. J Intern Med 2001, 249(1):27-40.

56. Kong ZQ, Fu CY, Chen Q, Wang R: Cardiovascular responses to intravenous administration of human hemokinin-1 and its truncated form hemokinin-1(4-11) in anesthetized rats. Eur J Pharmacol 2008, 590(13):310-316.

57. Bardelli C, Gunella G, Varsaldi F, Balbo P, Del Boca E, Bernardone IS, Amoruso A, Brunelleschi S: Expression of functional NK1 receptors in human alveolar macrophages: superoxide anion production, cytokine release and involvement of NF-kappaB pathway. Br J Pharmacol 2005, 145(3):385-396.

58. Lieb K, Fiebich BL, Busse-Grawitz M, Hull M, Berger M, Bauer J: Effects of substance $P$ and selected other neuropeptides on the synthesis of interleukin- 1 beta and interleukin-6 in human monocytes: a reexamination. J Neuroimmunol 1996, 67(2):77-81.

59. Brunelleschi S, Guidotto S, Viano I, Fantozzi R, Pozzi E, Ghio P, Albera C: Tachykinin activation of human alveolar macrophages in tobacco smoke and sarcoidosis: a phenotypical and functional study. Neuropeptides 1996, 30(5):456-464.
60. Pujol JL, Bousquet J, Grenier J, Michel F, Godard P, Chanez P, de Vos C, Crastes de Paulet A, Michel FB: Substance $P$ activation of bronchoalveolar macrophages from asthmatic patients and normal subjects. Clin Exp Allergy 1989, 19(6):625-628.

61. Derocq JM, Segui M, Blazy C, Emonds-Alt X, Le Fur G, Brelire JC, Casellas P. Effect of substance $P$ on cytokine production by human astrocytic cells and blood mononuclear cells: characterization of novel tachykinin receptor antagonists. FEBS Lett 1996, 399(3):321-325.

62. Lundberg JM, Hokfelt T, Martling CR, Saria A, Cuello C: Substance Pimmunoreactive sensory nerves in the lower respiratory tract of various mammals including man. Cell Tissue Res 1984, 235(2):251-261.

63. Ollerenshaw SL, Jarvis D, Sullivan CE, Woolcock AJ: Substance P immunoreactive nerves in airways from asthmatics and nonasthmatics. Eur Respir J 1991, 4(6):673-682.

64. Nieber K, Baumgarten CR, Rathsack R, Furkert J, Oehme P, Kunkel G: Substance $\mathrm{P}$ and beta-endorphin-like immunoreactivity in lavage fluids of subjects with and without allergic asthma. J Allergy Clin Immunol 1992, 90(4 Pt 1):646-652

65. Tomaki M, Ichinose M, Miura M, Hirayama Y, Yamauchi H, Nakajima N, Shirato K: Elevated substance $P$ content in induced sputum from patients with asthma and patients with chronic bronchitis. Am J Respir Crit Care Med 1995, 151(3 Pt 1):613-617.

66. Cardell LO, Uddman R, Edvinsson L: Low plasma concentrations of VIP and elevated levels of other neuropeptides during exacerbations of asthma. Eur Respir J 1994, 7(12):2169-2173.

doi:10.1186/1465-9921-11-139

Cite this article as: Grassin-Delyle et al:: Expression and function of human hemokinin-1 in human and guinea pig airways. Respiratory Research 2010 11:139.

\section{Submit your next manuscript to BioMed Central and take full advantage of:}

- Convenient online submission

- Thorough peer review

- No space constraints or color figure charges

- Immediate publication on acceptance

- Inclusion in PubMed, CAS, Scopus and Google Scholar

- Research which is freely available for redistribution
C Biomed Central 